\title{
Mesenchymal stromal cell-based therapy in kidney diseases and transplantation
}

\author{
Federica Casiraghi, Giuseppe Remuzzi \\ Istituto di Ricerche Farmacologiche Mario Negri IRCCS, Bergamo, Italy
}

\begin{abstract}
Intense investigation in pre-clinical models of kidney disease and transplantation showed that mesenchymal stromal cell (MSC) therapy acts on renal and inflammatory cells in multiple, complex and integrated ways, resulting in cell repair and regeneration, in the inhibition of inflammatory cells, and in the development of cells endowed with their own anti-inflammatory and immuneregulatory properties. These encouraging data paved the way for exploring the use of MSC in clinics as innovative therapeutic tools for patients with renal diseases and transplantation. In this review, we describe the available results of clinical studies of MSC in patients with post-cardiac surgery, acute kidney injury, chronic kidney diseases - including diabetes, renovascular disease and lupus nephritis - and in kidney transplant recipients, with a particular focus on our experience with MSC therapy as a pro-tolerogenic strategy in kidney transplantation. The available studies, mainly phase 1, indicated that MSC therapy is safe and feasible and not associated with adverse events, at least in the short- and mid-term. Encouraging results have been reported in renovascular disease and kidney transplantation, while studies in acute kidney injury and chronic kidney disease had contrasting outcomes. The relevant issues and the knowledge gap that still limit the translation of MSC cell therapy into clinical practice are discussed briefly.
\end{abstract}

\section{Mesenchymal stromal cells}

Mesenchymal stromal cells (MSC) are a heterogeneous population of non-hematopoietic cells obtained

Correspondence: Giuseppe Remuzzi, Istituto di Ricerche Farmacologiche Mario Negri IRCCS, Centro Anna Maria Astori, Kilometro Rosso Science and Technology Park, via Stezzano 87,24126 Bergamo, Italy.

Tel.: +39.035.4213401 - Fax: +39.035.319331

E-mail: giuseppe.remuzzi@marionegri.it

Key words: Mesenchymal stromal cells; acute kidney injury; chronic kidney disease; diabetic kidney disease; kidney transplantation.

Funding: this work was supported by the European Union's Horizon 2020 Research and Innovation Program under Grant Agreement no. 634086 (the NEPHSTROM study) and by the Fondazione ART per la Ricerca sui Trapianti, Milano, Italy.

Contributions: FC researched the data and wrote the article; GR made substantial contributions to content discussions and reviewed the manuscript.

Conflict of interest: the authors declare no conflict of interest.

Received for publication: 30 July 2018.

Accepted for publication: 22 August 2018.

This work is licensed under a Creative Commons Attribution NonCommercial 4.0 License (CC BY-NC 4.0).

(C) Copyright F. Casiraghi and G. Remuzzi, 2019

Licensee PAGEPress, Italy

Italian Journal of Medicine 2019; 13:3-14

doi:10.4081/itjm.2019.1072 after ex vivo expansion of adherent cells from bone marrow, ${ }^{1}$ adipose tissue, ${ }^{2}$ umbilical cord $^{3}$ and blood ${ }^{4}$ and other tissues. ${ }^{5}$ Despite the intense debate in the scientific community about their nature, in vivo counterpart and definition, MSC - irrespective of their tissue origin - are still defined by the minimal criteria established 10 years ago by the International Society for Cellular Therapy (ISCT), ${ }^{6}$ i.e.: plastic adherence under standard culture conditions, expression of CD105, CD73 and CD90 molecules, being negative for the expression of CD45, CD34, CD19 and CD79 molecules, and trilineage (chondrocyte, adipocyte and osteoblast) differentiation in vitro in the presence of proper growth factors. ${ }^{6}$ Ex vivo expanded MSC product displays unique pro-regenerative, reparative, anti-inflammatory and immunomodulatory properties that have stimulated the development of MSC as innovative therapy for inflammatory and immune-mediated diseases. The ease with which they expand and their immune-evasive phenotype have encouraged small and medium-sized businesses and big pharmaceutical companies to invest in the commercial and large-scale production of wellcharacterized, high-quality, low-cost MSC preparations readily available for clinical use. ${ }^{7,8}$

Over the past two decades, intense investigation into kidney disease and transplant models has shown that MSC perform multiple, integrated and complex actions targeting every single renal cell, eventually resulting in the activation of reparative and pro-regenerative programs in tubular and glomerular cells, ${ }^{9-32}$ in the inhibition of effector functions of inflammatory cells $\mathrm{s}^{33-44}$ and in the conversion of immune cells, such as macrophages, dendritic and $\mathrm{T}$ cells into cells endowed 
with their own immune-regulatory functions ${ }^{45-51}$ (Figure 1). These encouraging pre-clinical data paved the way for exploring, in clinics, the use of MSC as an innovative therapeutic tool for patients with renal diseases and transplants.

In this review we describe the results of the clinical experiences with MSC of patients with acute kidney injury, chronic kidney diseases and kidney transplantation, with a particular focus on our experience with MSC therapy as a pro-tolerogenic strategy in kidney transplantation.

\section{Acute kidney injury}

Acute kidney injury (AKI) is a frequent and essentially treatment-resistant complication that is caused by different insults such as ischemia-reperfusion, nephrotoxins and sepsis. ${ }^{52-55}$ It is characterized by acute tubular cell death, damage to endothelial cells and microvessels, and by intense inflammation. AKI has a high morbidity and mortality rate and only conservative treatments are available. ${ }^{56}$ Moreover, even if patients survive their acute illness, the incompletely resolved inflammatory and fibrotic processes lead, in a significant proportion of patients, to chronic renal failure. . $^{5,57}$

Based on encouraging preclinical data (Figure 1), phase $1 / 2$ clinical studies in patients with AKI have been undertaken ${ }^{58-60}$ (Table $1^{58-74}$ ), using the commercial allogeneic bone marrow (BM)-MSC AC607 product (Allocure). In a safety clinical study, 16 patients undergoing cardiac surgery and at particularly high risk of post-operative AKI received dose-escalating BM-MSC treatment at the end of surgery to prevent AKI development. The data indicate that MSC infusion was safe and feasible and the length of the hospital stay and readmission rates were reduced in MSC-treated individuals compared to historical case controls. In all MSC-treated patients, post-operative renal function remained stable and did not deteriorate during the 16-month follow-up in patients with underlying chronic kidney disease (CKD). ${ }^{58,59}$

These positive clinical data have, however, been challenged by the very recently published results of a randomized, double-blind, placebo-controlled study of AC607-MSC in patients with established post-cardiac surgical $\mathrm{AKI}^{60}$ (Table 1). The study randomized 156 adult subjects with laboratory evidence of postoperative AKI (rise of $0.5 \mathrm{mg} / \mathrm{dL}$ in serum creatinine during the $48 \mathrm{~h}$ following removal of cardiopulmonary bypass) to receive intra-aortic MSC or placebo infusion. After $75 \%$ patient accrual, the trial was halted for futility, because no difference in time to kidney recovery, rate of dialysis or 30-day mortality was found between patients given MSC or placebo. ${ }^{60}$

This study argues against the real utility of MSC therapy in clinical AKI. However, it should be consid- ered that, compared to the prior explorative clinical study and studies in pre-clinical models, in this study better designed with appropriate sample size MSC were however infused when serum creatinine had already increased considerably. This approach could have entailed a delayed diagnosis of AKI, since it is known that creatinine accumulates in the serum 1-2 days after the onset of AKI, and MSC were consequently administered in a context of overwhelming injury.

Thus, it remains to be established whether MSC are more effective for preventing than treating AKI, and whether earlier intervention - guided by more sensitive biomarkers such as Kim-1 and NGAL, ${ }^{61-63}$ whose levels increase early during the initiation phase of AKI - can still limit ongoing injury.

We designed a clinical trial to evaluate the safety and feasibility of systemic infusion of allogeneic BMMSC in patients with solid organ cancers who develop AKI after chemotherapy with cisplatin. In this study, escalating doses of BM-MSC would have been i.v. infused in patients showing evidence of AKI, defined as a $>3500 \%$ increase over baseline values of urinary NGAL concentrations at day 2 post-cisplatin infusion (NCT01275612). However, despite extensive screening, none of the seventeen screened patients met this primary criterion of acute renal failure development and the study was recently halted.

\section{Chronic kidney disease}

Chronic kidney disease is a syndrome of progressive deterioration of kidney function over time with significant implications for patients' health. ${ }^{64}$ Nowadays, CKD has become a public health priority, as highlighted by the Global Burden of Diseases (GBD) 2016 study, which ranked CKD as the nineteenth cause of mortality, compared to its 1990 ranking, when CKD was ranked the twenty-seventh cause of mortality. Despite renoprotective therapies, such as blockade of the renin-angiotensin system, a consistent proportion of CKD patients progress to endstage renal failure, requiring renal replacement therapy. ${ }^{64,65}$

So far, two clinical studies have evaluated the effects of autologous BM-MSC ${ }^{66}$ or extracellular vesicles derived from umbilical cord (UC)-MSC ${ }^{67}$ in patients with CKD (Table 1). In a single-center study, seven patients with non-diabetic CKD were given an intravenous infusion of autologous BM-MSC. ${ }^{66}$ The infusion was safe and no adverse events were observed. The patients were followed-up until 18 months post-cell infusion and clinical parameters recorded during this period were compared to those recorded from the 18 months prior to enrolment to cell infusion. No significant differences in serum creatinine levels and estimated glomerular filtration rate (eGFR) were found between the two study periods, ruling out the possibility that 
MSC had a significant effect on renal function. ${ }^{66} \mathrm{How}-$ ever, the low number of patients with very heterogeneous causes of CKD, as well as the advanced stage of most patients included in this study (four out of the seven patients developed end-stage renal disease requiring renal replacement therapy during or immediately after the 18-month follow-up), do not make any generalized conclusions about the efficacy of BM-MSC therapy in CKD possible.

In a single-center, randomized, placebo-controlled pilot study ${ }^{67} 40$ patients with CKD were randomized to receive placebo or two doses of extracellular vesicles (EV) isolated from UC-MSC (Table 1). The procedure was safe. Patients given MSC-EV showed an increase in eGFR and a reduction in blood urea and creatinine levels during the 12-month follow-up, not observed in the placebo group, suggesting a trend towards transient improvement in kidney function following EV injections. ${ }^{67}$ These findings should be confirmed in future clinical trials using, however, well

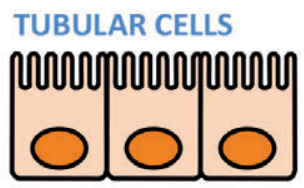

- Inhibition of apoptosis

- Acceleration of proliferation

- Mitochondrial protection

- Reduction of oxidative stress

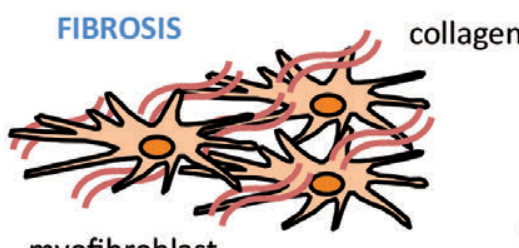

myofibroblast

- Prevention of interstitial fibrosis

- Reduction of collagen deposition -Reversion of EMT

-Increase of anti-fibrotic and reduction of pro- fibrotic molecules

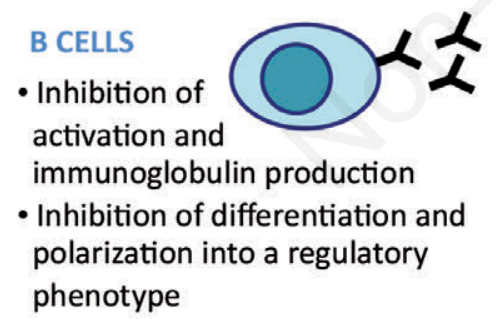

ENDOTHELIAL CELLS

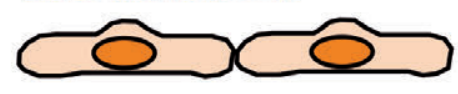

- Reduction of injury and activation

- Attenuation of capillary loss

- Increase in capillary vessel density

- Increase in angiogenesis

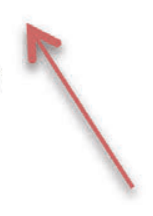

$\leftarrow$ MSC

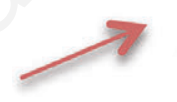

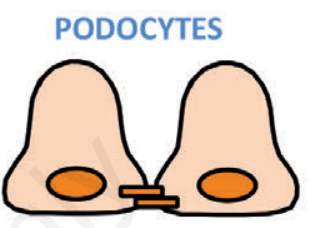

- Reduction of effacement and widening of foot processes

- Preservation of slit diaphragm protein expression

- Inhibition of apoptosis

- Reduction of GBM thickening

\section{INFLAMMATION}

- Reduction of pro-inflammatory cytokine and increase in antiinflammatory cytokine expression
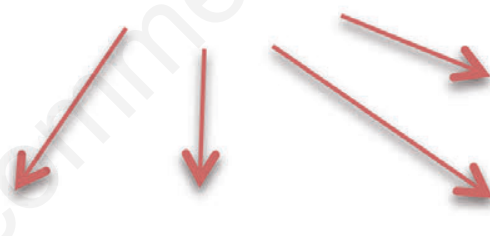

MACROPHAGES

- Reduction of

kidney infiltration

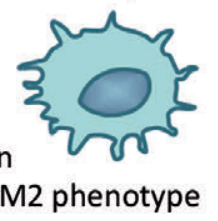
DENDRITIC CELLS
- Polarization into a pro-tolerogenic immature phenotype

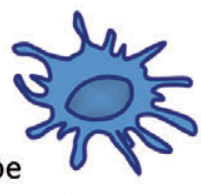
- Decrease of T cell stimulatory properties
-Impairment of migration toward lymphoid organs

- Polarization into M2 phenotype

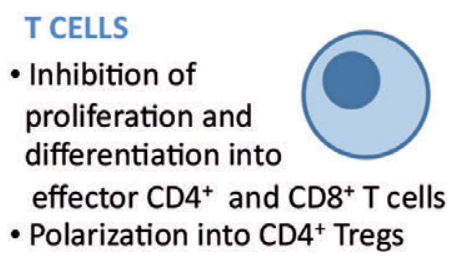

T CELLS

- Inhibition of proliferation and differentiation into

- Polarization into $\mathrm{CD}^{+}$Tregs

Figure 1. Mesenchymal stromal cells (MSC) actions on renal and inflammatory cells in kidney disease and transplant models. MSC or their secretome limit apoptosis and oxidative stress ${ }^{9-13}$ of tubular cells, promote cell proliferation ${ }^{9-14}$ and trafficking of mitochondria between adjacent tubular cells, ${ }^{15}$ eventually accelerating renal repair ${ }^{15,16}$ and preventing renal disease progression ${ }^{17}$ in experimental models of acute kidney injury induced by cisplatin, ${ }^{9-11}$ glycerol ${ }^{12}$ or by ischemia/reperfusion injury. ${ }^{13,18}$ MSC inhibit endothelial cell injury and increase capillary vessel density, ${ }^{10,19,20}$ reduce podocyte apoptosis and preserve the expression of slit diaphragm proteins, ${ }^{21-24}$ limit interstitial fibrosis ${ }^{25}$ by decreasing collagen, fibronectin and a-SMA expression and deposition, ${ }^{26-28}$ reduce inflammatory cell infiltration ${ }^{23,25,29-31}$ and expression of pro-inflammatory cytokines. Thus, MSC hinder pathological renal structural alteration and preserve renal function in CKD, chronic kidney disease models, such as subtotal nephrectomy ${ }^{25}$ ureteral obstruction, ${ }^{26,27,32}$ renal artery stenosis, ${ }^{19,20}$ diabetes ${ }^{23,24,29-31}$ and adriamycin-induced nephropathy proteins. ${ }^{21,22}$ In addition, MSC inhibit the activation and effector function of $\mathrm{T}$ cells, ${ }^{33-36}$ dendritic cells, ${ }^{37,38}$ macrophages ${ }^{39}$ and $\mathrm{B}$ cells, ${ }^{40}$ converting them into regulatory cells, ${ }^{45-48}$ eventually prolonging murine kidney allograft survival, ${ }^{49-51}$ and decreasing proteinuria and autoantibody production, ${ }^{41,42}$ and prolonging life-span in lupus nephritis models. ${ }^{43,44}$ 
Table 1. Clinical studies in acute and chronic kidney diseases.

\begin{tabular}{|c|c|c|c|c|}
\hline NCT (ClinicalTrial.gov) & MSC & Patients & $\begin{array}{l}\text { Study arms } \\
\text { (follow-up) }\end{array}$ & Main results \\
\hline \multicolumn{5}{|c|}{ Acute kidney injury } \\
\hline NCT00733876 (phase 1) ${ }^{58,59}$ & $\begin{array}{l}\text { Single intra-aortic } \\
\text { injection, dose-escalating } \\
\text { (doses not specified), of } \\
\text { commercial BM-derived } \\
\text { MSC (Allocure) }\end{array}$ & $\begin{array}{l}\mathrm{n}=16 \text { - patients } \\
\text { undergoing cardiac } \\
\text { surgery at a high risk of } \\
\text { AKI (underlying kidney } \\
\text { disease, advanced age, } \\
\text { diabetes, congestive heart } \\
\text { failure, chronic obstructive } \\
\text { lung disease, prolonged } \\
\text { pump time) }\end{array}$ & $\begin{array}{l}\text { Single-arm, comparison } \\
\text { with historical controls } \\
\text { (16 months) } \\
\text { e }\end{array}$ & $\begin{array}{l}\text { Safety and feasibility } \\
\text { Renal function remained } \\
\text { stable early and at the end of } \\
\text { follow-up } \\
\text { Reduced length of hospital } \\
\text { stay and readmission rate }\end{array}$ \\
\hline NCT01602328 (phase 2) $)^{60}$ & $\begin{array}{l}\text { Single intra-aortic } \\
\text { injection of } 2 \times 10^{6} / \mathrm{kg} \\
\text { of commercial } \\
\text { BM-derived MSC } \\
\text { (Allocure) }\end{array}$ & $\begin{array}{l}\mathrm{n}=67 \text { - patients with } \\
\text { established post-cardiac } \\
\text { surgery AKI }\end{array}$ & $\begin{array}{l}\text { Placebo-controlled } \\
\text { (30 days) }\end{array}$ & $\begin{array}{l}\text { Halted due to futility } \\
\text { No differences in time to } \\
\text { recovery of kidney function } \\
\text { (primary outcome) and in rate } \\
\text { of dialysis and 30-day } \\
\text { mortality between MSC and } \\
\text { placebo treatment }\end{array}$ \\
\hline
\end{tabular}

\begin{tabular}{|c|c|c|c|}
\hline & & Chronic kidney disease & \\
\hline NCT02195323 (phase 1) ${ }^{66}$ & $\begin{array}{l}\text { Single intravenous } \\
\text { infusion of } 1-2 \times 10^{6} / \mathrm{kg} \\
\text { autologous BM-MSC }\end{array}$ & $\begin{array}{l}\mathrm{n}=7 \text { - patients with } \\
\text { non-diabetic CKD } \\
\text { (probable hypertension, } \\
\mathrm{n}=3 \text {; nephrotic syndrome, } \\
\mathrm{n}=3 \text {; or of unknown } \\
\text { etiology, } \mathrm{n}=1 \text { ); } \\
\text { eGFR: } 25-44 \mathrm{~mL} \text { / } \\
\min / 1.73 \mathrm{~m}^{2}\end{array}$ & $\begin{array}{l}\text { Single-arm, within } \\
\text { subject comparison } \\
\text { (18 months) }\end{array}$ \\
\hline
\end{tabular}

Safety and feasibility No significant changes in kidney function (eGFR and serum creatinine)

\begin{tabular}{|c|c|c|c|c|}
\hline Not registered (phase 1$)^{67}$ & $\begin{array}{l}\text { An intravenous injection } \\
\text { followed by a second } \\
\text { intra-arterial injection } \\
\text { ( } 7 \text { days apart) of } 100 \mu \mathrm{g} / \\
\mathrm{kg} / \text { dose of UC-MSC EV } \\
\text { (corresponding to } 1 \times 10^{6} \\
\mathrm{MSC} / \mathrm{kg} / \text { dose) }\end{array}$ & $\begin{array}{l}\mathrm{n}=20 \text { - patients with } \mathrm{CKD} \\
\text { (hypertension, } \mathrm{n}=15 \text {; } \\
\text { T1 diabetes, } \mathrm{n}=10 \text {; } \\
\text { interstitial nephritis, } \mathrm{n}=5 \text {, } \\
\mathrm{SLE}, \mathrm{n}=3 \text {; eGFR: } \\
15-60 \mathrm{~mL} / \mathrm{min} / 1.73 \mathrm{~m}^{2}\end{array}$ & $\begin{array}{l}\text { Placebo-controlled } \\
\text { (12 months) }\end{array}$ & $\begin{array}{l}\text { Safety and feasibility. } \\
\text { eGFR, the urinary albumin to } \\
\text { creatinine ratio and serum } \\
\text { creatinine levels improved in } \\
\text { a non-significant manner in } \\
\text { the MSC-EV treated, but not } \\
\text { in the control group }\end{array}$ \\
\hline NCT02266394 (phase1/2a) ${ }^{69}$ & $\begin{array}{l}\text { Single intra-renal artery } \\
\text { injection of escalating dose } \\
\left(1 \times 10^{5} / \mathrm{kg} \text { or } 2.5 \times 10^{5} / \mathrm{kg}\right) \\
\text { of autologous AT-MSC }\end{array}$ & $\begin{array}{l}\mathrm{n}=7+7 \text { - patients with } \\
\text { atherosclerotic } \\
\text { renovascular disease }\end{array}$ & $\begin{array}{l}\text { Compared with a } \\
\text { matched-cohort } \\
\text { ( } 3 \text { months) }\end{array}$ & $\begin{array}{l}\text { Safety and feasibility } \\
\text { Increased cortical perfusion } \\
\text { and renal blood flow, stable } \\
\text { eGFR }\end{array}$ \\
\hline NCT01843387 (phase 1/2a) ${ }^{70}$ & $\begin{array}{l}\text { Single intravenous } \\
\text { injection of } 150 \times 10^{6} \text { or } \\
300 \times 10^{6} \text { commercial } \\
\text { BM-derived MPC } \\
\text { (rexlemestrocel-L) }\end{array}$ & $\begin{array}{l}\mathrm{n}=10+10 \text { - patients with } \\
\text { moderate to severe } \\
\text { diabetic kidney disease } \\
\text { eGFR: } 20-50 \mathrm{~mL} / \mathrm{min} / \\
1.73 \mathrm{~m}^{2}\end{array}$ & $\begin{array}{l}\text { Placebo-controlled } \\
\text { ( } 60 \text { weeks) }\end{array}$ & $\begin{array}{l}\text { Safety and feasibility } \\
\text { Trend toward stabilized } \\
\text { improved renal function }\end{array}$ \\
\hline $\begin{array}{l}\text { NCT0069819172 } \\
\text { NCT01741857 }\end{array}$ & $\begin{array}{l}\text { Single intravenous } \\
\text { infusion of } 1 \times 10^{6} / \mathrm{kg} \text { of } \\
\text { either allogeneic } \\
\text { BM- }(n=23 \text { pts }) \text { or } \\
\text { UC- }(n=58) \text { MSC }\end{array}$ & $\begin{array}{l}\mathrm{n}=81 \text { - patients with } \\
\text { lupus nephritis refractory } \\
\text { to standard therapy } \\
\text { (at least } 6 \text { months of } \\
\text { cyclophosphamide /or } \\
\text { MMF and steroids) }\end{array}$ & $\begin{array}{l}\text { Single-arm } \\
(12 \text { months }) \\
(5 \text { years })\end{array}$ & $\begin{array}{l}12 \text { months: } 95 \% \text { survival, } \\
60 \% \text { patients achieved renal } \\
\text { remission with a relapse rate } \\
\text { of } 24 \% \\
\text { Amelioration of lupus } \\
\text { nephritis activity } \\
5 \text { years: } 84 \% \text { survival, } \\
34 \% \text { of patients in remission, } \\
5 \text { year-overall-relapse rate of } \\
24 \% \text {. } \\
\text { Continuous improvement in } \\
\text { lupus nephritis activity }\end{array}$ \\
\hline NCT01539902 (phase 2) $)^{74}$ & $\begin{array}{l}\text { Two intravenous infusions } \\
\text { of } 5 \times 10^{7} \text { cells/each dose, } \\
\text { seven days apart of } \\
\text { UC-MSC }\end{array}$ & $\begin{array}{l}\mathrm{n}=12 \text { - patients with } \\
\text { lupus nephritis } \\
\text { (WHO class III and IV) }\end{array}$ & $\begin{array}{l}\text { Placebo-controlled } \\
\text { (12 months) }\end{array}$ & $\begin{array}{l}\text { Discontinued } \\
\text { Remission rate and } \\
\text { improvement in disease } \\
\text { activity comparable to patients } \\
\text { given placebo }\end{array}$ \\
\hline
\end{tabular}

MSC, mesenchymal stromal cells; BM, bone marrow; AKI, acute kidney injury; CKD, chronic kidney disease; eGFR, estimated glomerular filtration rate; EV, extracellular vesicles; SLE, systemic lupus erythematosus; AT, adipose tissue; UC, umbilical cord; MPC, mesenchymal precursor cells; MMF, mycophenolate mofetil; WHO, World Health Organization. 
characterized EV preparation that fit better with the recommendations of the International Society of Extracellular Vesicles (ISEV) ${ }^{68}$ regarding the quality and characterization of the cell product.

\section{Renovascular disease}

In an open-label, single-center, dose-escalation trial, ${ }^{69} 14$ patients with renovascular disease received an intra-arterial injection of autologous adipose-tissue derived MSC in the stenotic kidney on top of standardized medical treatment (Table 1). Control patients matched for age, kidney function and severity of stenosis received only the medical treatment. MSC treatment was well-tolerated and was associated with a significant increase in renal cortical blood flow, perfusion and renal oxygenation, both in the stenotic and the contralateral kidney, whereas no changes were observed in control patients. In MSC-treated patients, GFR measured by iothalamate clearance was preserved, compared to control patients in whom GFR underwent a significant decline. ${ }^{69}$

The positive findings of this study underline MSC as a promising therapeutic application for ameliorating vascular insufficiency and inflammatory injury in ischemic kidney disease.

\section{Diabetic kidney disease}

In a randomized, double-blind, dose-escalating placebo-controlled study, type 2 diabetes (T2D) patients with moderate to severe diabetic kidney disease (DKD) were randomized to receive placebo or intravenous injections of an escalating dose of $150 \times 10^{6}$ or $300 \times 10^{6}$ mesenchymal precursor cell (rexlemestrocel$\mathrm{L})^{70}$ (Table 1). Cell infusion was well tolerated and no adverse events were observed during the 60 -week follow-up. As the explorative efficacy endpoint, estimated and measured GFR changes from baseline to 12 weeks post-treatment were evaluated, and results indicated a trend towards stabilized or improved estimated and measured GFR in patients given rexlemestrocel, irrespective of the dose. ${ }^{70}$ These data, demonstrating the safety and feasibility of the procedure, should be confirmed in larger and powered clinical trials, possibly aimed at evaluating whether multiple MSC infusions can foster the minimal beneficial effect on renal function observed in this study.

We are coordinating a multicenter European study (the Novel Stromal Cell Therapy for Diabetic Kidney Disease, the NEPHSTROM study, NCT02585622) with a standardized cell product (the allogeneic BMMSC preparation ORBCEL-M, Orbsen Therapeutics) in T2D patients with progressive DKD and mild to moderate renal insufficiency. Patients are randomized to placebo or to an escalating dose of MSC $\left(80 \times 10^{6}\right.$, $160 \times 10^{6}$, and $\left.240 \times 10^{6}\right)$. The primary outcome is safety and feasibility of ORBCEL-M administration, with a pilot explorative efficacy outcome on the effect of the cellular therapy on a measured GFR decline over a study period of 18 months.

\section{Lupus nephritis}

MSC therapy in patients with systemic lupus erythematosus (SLE) has been conducted in China, mainly by the Sun et al..$^{71-73}$ group and, more recently by Deng et al. ${ }^{74}$ with contrasting results (Table 1).

Starting from a preliminary observation of clinical improvement in 4 SLE patients given an i.v. infusion of allogeneic BM-MSC, ${ }^{71}$ overall more than 80 patients with severe and drug-refractory SLE were treated with BM- or UC-MSC by the Sun group. ${ }^{72,73}$ In a report focusing specifically on the 12-month follow-up of 81 patients with lupus nephritis unresponsive to conventional immunosuppressive treatment, ${ }^{72}$ the authors found that either BM- or UC-MSC treatment induced partial or complete renal remission in $60 \%$ of patients. Total SLE disease activity index (SLEDAI) and British Isles Lupus Assessment Group (BILAG) renal activity scores declined significantly compared to baseline values; proteinuria also decreased, and GFR improved. However, during the 12month follow-up, $24 \%$ of patients who had previously achieved renal remission experienced relapse. A significant correlation between remission and baseline proteinuria and creatinine levels was found, suggesting that baseline renal disease severity can influence the response to cell therapy. ${ }^{72}$ The recent paper on the long-term follow-up of the overall population of lupus patients given MSC cell therapy at this center ${ }^{73}$ reports a 5 -year overall survival rate of $84 \%$, complete or partial clinical remission in $27 \%$ and $7 \%$ of patients, respectively, and an overall relapse rate of $24 \% .{ }^{73}$ Overall, this clinical experience suggests that MSC could be a real therapeutic option for SLE patients refractory to conventional treatments. However, these studies lacked a control group and well-designed and placebo-controlled clinical trials are needed to demonstrate MSC efficacy in SLE.

Along similar lines, a randomized, double-blind, placebo-controlled trial recently assessed the effect of UC-MSC in patients with severe lupus nephritis ${ }^{74}$ (Table 1). Eighteen patients were randomized in a 2:1 ratio to receive double i.v. infusions of UC-MSC or placebo. All patients received induction therapy with intravenous methylprednisolone and cyclophosphamide and maintenance immunosuppression with oral prednisolone and mycophenolate mofetil (MMF). The results showed that a similar proportion of patients in the UC-MSC and placebo groups achieved remission. SLEDAI and BILAG scores and renal function improved in both groups at a comparable level. The trial was discontinued after the enrolment 
of the first 18 patients, when the investigators considered that the trial had failed to demonstrate any additional beneficial effects of UC-MSC therapy over standard immunosuppression. ${ }^{74}$ This study did not confirm previous, encouraging pilot studies in patients with SLE. However, it should be taken into account that the study by Deng et al. enrolled patients with newly diagnosed lupus nephritis who were given induction immunosuppressive treatment including cyclophosphamide and MMF, drugs known to be effective in inducing remission of lupus nephritis in the short-term. ${ }^{75,76}$ Indeed, five out of six patients in the control arm underwent remission, to the point that additional benefits from MSC on top of the already effective induction therapy could not be demonstrated.

Overall, no definitive conclusion can be drawn on the basis of current knowledge of lupus nephritis, even though MSC appear to be a promising second-line intervention for patients who are refractory to conventional immunosuppressive treatment and have moderate renal disease.

\section{Kidney transplantation}

Patients with kidney transplantation still receive life-long immunosuppression to prevent graft rejection, exposing them to a substantial risk of infections, malignancies and life-threatening drug side effects. Moreover, current immunosuppression performs poorly in preventing the development of chronic allograft nephropathy. Therefore, novel strategies to induce immunological tolerance and to reduce immunosuppression are needed.

In several pre-clinical models of organ transplantation, including skin, ${ }^{77}$ the heart, ${ }^{49,78}$ and kidney,,${ }^{50,51,79}$ the infusion of MSC resulted in significant graft survival prolongation. MSC mitigate the anti-graft $\mathrm{T}$ cell immune response, ${ }^{49-51,77-79}$ and, by inducing regulatory dendritic cells ${ }^{78}$ or regulatory $\mathrm{T}$ cells, ${ }^{49-51,79}$ also promote the induction and maintenance of immunological tolerance (reviewed in ${ }^{80}$ ).

Several small pilot studies ${ }^{81-86}$ and a large clinical trial conducted in China ${ }^{87}$ assessed safety and feasibility and explored initial efficacy of autologous ${ }^{81,84-87}$ or third-party (from a subject unrelated to the organ donor and to the recipient) $\mathrm{BM}^{-82}$ or $\mathrm{UC}^{8}{ }^{83} \mathrm{MSC}$ in kidney transplantation to alleviate chronic histological damage and subclinical rejection, ${ }^{81}$ to enable anti-rejection drug minimization ${ }^{82,83,87}$ and promote the development of immunological tolerance toward the graft $^{84-86}$ (Table ${ }^{81-87}$ ).

In a small study, ${ }^{81}$ autologous BM-MSC were infused twice in six living-donor kidney transplant recipients showing signs of subclinical rejection and/or increases in interstitial fibrosis/tubular atrophy (IF/TA) on their 6-month protocol biopsies (Table 2). Cell infusions were tolerated well and surveillance biopsies performed in two patients after MSC treatment showed tubulitis and IF/TA resolution. However, three patients developed an opportunistic viral infection, raising concerns regarding generalized immunosuppression after MSC treatment. ${ }^{81}$

This concern was allayed by a large Chinese clinical trial that used MSC infusion to replace induction therapy with the anti CD25-antibody, basiliximab, in living-donor kidney transplant recipients ${ }^{87}$ (Table 2). Living-donor kidney transplant patients were randomized into 3 study groups: patients given autologous BM-MSC and either standard-dose $(\mathrm{n}=53)$ or $80 \%$ of the standard calcineurin-inhibitor $(\mathrm{CNI})$ dose $(\mathrm{n}=52)$ or given induction therapy with basiliximab and standard CNI dose ( $\mathrm{n}=51$, control group). In this study, a significantly decreased risk of opportunistic infection was observed in MSC-treated patients compared to controls, alleviating concerns regarding possible global immunosuppression following MSC therapy in already immunocompromised kidney transplant recipients. Moreover, MSC-treated patients had faster renal function recovery during the first month and a significantly reduced incidence of acute rejection 6 months post-transplant, compared to the control group, in which an unexpectedly higher percentage of patients (22\%) experienced acute rejection. The incidence of acute rejection at 1 year post-transplant was similar among patient groups. This study confirms that autologous BM-MSC infusion is safe and that MSC therapy can effectively replace basiliximab induction therapy and enable CNI dose reduction. ${ }^{87}$ Despite very encouraging results, this study did not attempt to evaluate the effect of MSC on recipient immune cells and also raised the question of whether costly MSC-based therapy should be used only as induction therapy to prevent acute rejection in kidney transplantation (a condition that is already controlled well by current low-cost immunosuppressive drugs).

A recent prospective multi-center study was performed using UC-MSC as induction therapy to prevent both delayed graft function (DGF) and acute rejection in deceased-donor kidney transplant recipients $^{83}$ (Table 2). Forty-two renal allograft recipients receiving paired graft donation were divided into the control or trial group and given a double infusion of UC-MSC. MSC-treated patients tolerated the cell infusion with no adverse events. The incidence of DGF and acute rejection and the kidney graft function (by eGFR levels) were similar in patients given and not given MSC therapy. ${ }^{83}$ In addition, this paired study was performed in kidney transplant recipients of nonECD kidneys (donor aged $<65$, no history of kidney disease, uncontrolled hypertension and diabetes), already at low risk of DGF development, thus making it difficult to detect any additional effect of MSC on DGF development. 
Other investigators evaluated the possibility of using lower doses of maintenance immunosuppressive drugs after allogeneic BM-MSC cell therapy ${ }^{82}$ (Table 2). Donor-derived (even though it is not clear whether MSC were from the organ donor or from an unrelated
$\mathrm{BM}$ donor) $\mathrm{BM}-\mathrm{MSC}$ were infused in 16 living related donor kidney transplant patients. MSC infusion was combined with a $50 \%$ dose of tacrolimus, while the control group received the standard tacrolimus dose. Patients were followed-up for 24 months. Graft and

Table 2. Clinical studies of mesenchymal stromal cells in kidney transplantation.

\begin{tabular}{|c|c|c|c|c|}
\hline NCT (ClinicalTrial.gov) & MSC & Patients & $\begin{array}{l}\text { Study arms } \\
\text { (follow-up) }\end{array}$ & Main results \\
\hline NCT00734396 (phase 1) $)^{81}$ & $\begin{array}{l}\text { Two intravenous infusions } \\
\text { of } 0.1-1 \times 10^{6} / \mathrm{kg} \text { autologous } \\
\text { BM-MSC, seven days } \\
\text { apart, } 6-10 \text { months } \\
\text { post-transplant }\end{array}$ & $\begin{array}{l}\mathrm{n}=6 \text { - living-donor } \\
\text { kidney transplant } \\
\text { recipients } \\
\text { Immunosuppressive } \\
\text { therapy: basiliximab } \\
\text { induction and } \\
\text { maintenance with CNI, } \\
\text { MMF and steroids }\end{array}$ & $\begin{array}{l}\text { Single arm } \\
\text { ( } 24 \text { weeks post-MSC } \\
\text { infusion) }\end{array}$ & $\begin{array}{l}\text { High incidence }(50 \%) \\
\text { of opportunistic } \\
\text { infections } \\
\text { Resolution of tubulitis and } \\
\text { IF/TA }\end{array}$ \\
\hline NCT00658073 (phase 2) ${ }^{87}$ & $\begin{array}{l}\text { Two intravenous } \\
\text { infusions of } 1-2 \times 10^{6} / \mathrm{kg} \\
\text { autologous BM-MSC } \\
\text { during surgery and } \\
2 \text { weeks later }\end{array}$ & $\begin{array}{l}\text { Living-donor kidney } \\
\text { transplant recipients } \\
\mathrm{n}=53 \text { combined with } \\
\text { standard CNI dose } \\
\mathrm{n}=52 \text { combined with } \\
80 \% \text { CNI dose } \\
\text { Immunosuppressive } \\
\text { therapy: no induction } \\
\text { therapy, maintenance } \\
\text { including MMF and } \\
\text { steroids }\end{array}$ & $\begin{array}{l}\text { Comparison with a } \\
\text { control group of } \mathrm{No}=51 \\
\text { patients given } \\
\text { basiliximab induction } \\
\text { therapy and standard } \\
\mathrm{CNI} \text { dose, MMF and } \\
\text { steroids } \\
\text { ( } 1 \text { year post-transplant) }\end{array}$ & $\begin{array}{l}\text { Increased eGFR during the } \\
\text { follow-up, lower incidence of } \\
\text { acute rejection at } 6 \text { but not at } \\
12 \text { months, decreased risk of } \\
\text { opportunistic infection }\end{array}$ \\
\hline NCT02490020 (phase 1$)^{83}$ & $\begin{array}{l}\text { An intravenous infusion } \\
\text { of } 2 \times 10^{6} / \mathrm{kg} \text { before } \\
\text { transplantation and a } \\
\text { second intra-renal } \\
\text { artery injection during } \\
\text { intervention of } 5 \times 10^{6} \\
\text { UC-MSC }\end{array}$ & $\begin{array}{l}\mathrm{n}=21 \text { - deceased-donor } \\
\text { kidney transplant } \\
\text { recipients } \\
\text { Immunosuppressive } \\
\text { therapy: induction with } \\
\text { antithymocyte globulin and } \\
\text { maintenance with CNI, } \\
\text { MMF and steroids }\end{array}$ & $\begin{array}{l}\text { Comparison with patients } \\
\text { given paired kidneys, } n=21 \\
\text { (1 year post-transplant) }\end{array}$ & $\begin{array}{l}\text { Safe and tolerated } \\
\text { Similar incidence of DGF and } \\
\text { acute rejection and kidney } \\
\text { graft function between } \\
\text { MSC-treated patients and } \\
\text { control group }\end{array}$ \\
\hline Not registered (phase 2) 82 & $\begin{array}{l}\text { A first intra-renal artery } \\
\text { injection during } \\
\text { intervention of } 5 \times 10^{6} \\
\text { cells and a second } \\
\text { intravenous infusion } \\
1 \text { month post-transplant } \\
\text { of } 2 \times 10^{6} / \mathrm{kg} \text { of allogeneic } \\
\text { BM-MSC }\end{array}$ & $\begin{array}{l}\mathrm{n}=16 \text { - living-donor } \\
\text { kidney transplant } \\
\text { recipients } \\
\text { Immunosuppressive } \\
\text { therapy: induction with } \\
\text { cytoxan and maintenance } \\
\text { with } 50 \% \text { tacrolimus } \\
\text { dose, } \mathrm{MMF} \text { and steroids }\end{array}$ & $\begin{array}{l}\text { Comparison with a } \\
\text { control group of } \\
\text { No=16 patients given } \\
\text { standard tacrolimus dose, } \\
\text { MMF, steroids and } \\
\text { cytoxan induction } \\
\text { ( } 2 \text { years post-transplant) }\end{array}$ & $\begin{array}{l}\text { MSC-treated patients } \\
\text { exhibited similar graft and } \\
\text { patient survival, acute } \\
\text { rejection incidence and graft } \\
\text { function compared to } \\
\text { control arm, suggesting that } \\
\text { MSC could allow safe } \\
\text { minimization of } \\
\text { maintenance immunotherapy }\end{array}$ \\
\hline NCT00752479 (phase 1) ${ }^{84,86}$ & $\begin{array}{l}\text { Single intravenous } \\
\text { infusion of } 1.7-2 \times 10^{6} / \mathrm{kg} \\
\text { autologous BM-MSC, } \\
7 \text { days post-transplant }\end{array}$ & $\begin{array}{l}\mathrm{n}=2 \text { - living donor kidney } \\
\text { transplant recipients } \\
\text { Immunosuppressive } \\
\text { therapy: induction with } \\
\text { basiliximab/low-dose } \\
\text { RATG and maintenance } \\
\text { with CsA and MMF }\end{array}$ & $\begin{array}{l}\text { Comparison with control } \\
\text { groups of living }(\mathrm{n}=3) \\
\text { or deceased ( } \mathrm{n}=3) \text { donor } \\
\text { kidney transplant patients } \\
\text { (1 year) (5-7 years) }\end{array}$ & $\begin{array}{l}\text { Transient renal insufficiency } \\
\text { following cell infusion } \\
\text { Donor-specific CD } 8^{+} \mathrm{T} \text { cell } \\
\text { unresponsiveness, high } \\
\text { Treg/memory CD } 8^{+} \mathrm{T} \text { cells } \\
\text { ratio; naïve and transitional } \\
\text { B cell expansion ( } 1 \text { patient) }\end{array}$ \\
\hline NCT02012153 (phase 1) & $\begin{array}{l}\text { Single intravenous } \\
\text { infusion of } 2 \times 10^{6} / \mathrm{kg} \\
\text { autologous BM-MSC, } \\
\text { the day before transplant }\end{array}$ & $\begin{array}{l}\mathrm{n}=2 \text { - living donor kidney } \\
\text { transplant recipients } \\
\text { Immunosuppressive } \\
\text { therapy: induction with } \\
\text { low-dose RATG and } \\
\text { maintenance with CsA } \\
\text { and MMF }\end{array}$ & $\begin{array}{l}\text { Comparison with control } \\
\text { groups of living }(\mathrm{n}=3) \\
\text { or deceased }(\mathrm{n}=6) \text { donor } \\
\text { kidney transplant } \\
\text { recipients ( } 1 \text { year) } \\
\text { (5-7 years) }\end{array}$ & $\begin{array}{l}\text { Safe and feasible } \\
\text { Donor-specific CD8 } 8^{+} \\
\text {T cell unresponsiveness, } \\
\text { High Treg/memory CD8 } \\
\text { T cells ratio; naïve and } \\
\text { transitional B cell expansion } \\
\text { (1 patient) } \\
\text { CsA withdrawal in one patient }\end{array}$ \\
\hline
\end{tabular}

MSC, mesenchymal stromal cells; BM, bone marrow; CNI, calcineurin inhibitors; MMF, mycophenolate mofetil; IF/TA, interstitial fibrosis/tubular atrophy; eGFR, estimated glomerular filtration rate; UC, umbilical cord; DGF, delayed graft function; RATG, rabbit anti-thymocyte globulin; CsA, cyclosporine A. 
patient survival, acute rejection, and graft function in the MSC-treated group did not differ from the control group, suggesting that MSC could enable safe minimization of maintenance immunotherapy. ${ }^{82}$

Overall, these studies demonstrated the safety and feasibility of the procedure and suggest MSC could have an immunomodulatory effect in kidney transplantation. However, most lack mechanistic studies to gain insights into the effect of MSC on the recipient anti-graft cell response.

In this regard, we are studying MSC therapy in kidney transplantation through a different approach. . $^{80,84-86}$

Based on experimental findings that the infusion of syngeneic BM-MSC induced cardiac graft survival prolongation in mice through the generation of donorspecific Tregs, ${ }^{49}$ we designed a pilot safety and feasibility study of autologous BM-MSC infusion in living-donor kidney transplant recipients. ${ }^{84} \mathrm{We}$ first performed in vitro studies to evaluate the effect of immunosuppressive drugs on MSC immunosuppressive function and found that rabbit anti-thymocyte globulin (RATG), used in our protocol as induction therapy, bound to MSC, implying a possible detrimental effect of RATG on cell viability if MSC were infused during induction therapy. We therefore timed MSC infusion at the end of RATG administration ( 7 days post-transplantation), a point in time that also coincided with homeostatic proliferation of residual immune cells. This time frame would allow MSC to push peripheral Treg expansion, while constraining the proliferation of memory T cells. Therefore, we enrolled the first 2 patients given autologous BM-MSC at 7 days posttransplantation. Unexpectedly, a few days after MSC infusion both patients developed transient renal insufficiency. Histological analysis of a kidney graft biopsy performed in the second patient excluded ongoing acute cellular rejection but revealed an inflammatory picture characterized by complement $\mathrm{C} 3$ deposits, infiltrating neutrophils and quite a few MSC. ${ }^{84}$ This led us to hypothesize that infused MSC were recruited into the graft inflammatory environment and activated to release inflammatory factors, amplifying graft inflammation. This hypothesis was indeed confirmed in a murine kidney transplant model ${ }^{79}$ leading us to move cell injection before transplantation. Two additional patients were recruited into the new protocol ${ }^{85}$ and given autologous BM-MSC the day before transplantation and induction therapy with RATG only (not combined with basiliximab) to avoid any possible inhibitory effect of the anti-CD25 antibody on MSC-induced Tregs. The third patient had excellent graft function recovery and his kidney function is stable after 7-year follow-up. The fourth patient experienced acute cellular rejection, likely due to inefficient control of acute cellular rejection of the induction therapy without basiliximab before MSC acquired the full capability to modulate the immune system..$^{85}$ Therefore, the protocol was implemented again, leaving out the pre-transplant infusion of MSC but now combined with Basiliximab/low-dose RATG. ${ }^{86}$ One patient has been enrolled in this clinical protocol with an uneventful post-transplant course. ${ }^{86}$ All MSC-treated patients have long-term stable graft function. ${ }^{86}$ In these patients, we performed extensive analysis of the immune cell phenotype and ex vivo anti-donor $\mathrm{T}$ cell alloreactivity and we were able to document the development of a pro-tolerogenic environment characterized by an increased ratio between Tregs and memory $\mathrm{CD} 8^{+} \mathrm{T}$ cells, and a long-lasting donor-specific hyporesponsiveness of cytotoxic $\mathrm{T}$ cells. These findings were particularly remarkable and sustained in one patient, in whom a progressive increase in circulating naïve and transitional B cells was observed, starting from the second post-transplant year. In this patient, who had neither evidence of subclinical rejection at the 1-year protocol biopsy nor de novo donor-specific antibodies development, we attempted immunosuppressive drug withdrawal. Cyclosporine A was successfully withdrawn first ${ }^{86}$ and, after few months on low-dose MMF monotherapy, the patient is currently free from immunosuppression, with progressively increasing measured GFR ${ }^{86}$ Thus, MSC infusion was safe, provided it was performed before transplantation and, by studying a small number of patients very extensively using cutting-edge immunological methods, we were able to demonstrate that MSC could influence the host immune response and promote a pro-tolerogenic environment in selected patients.

The know-how we have gained over the years regarding the safety and mechanistic immunological effects of MSC in living-donor kidney transplant patients allowed us to devise and conduct clinical trial in deceased-donor kidney transplant patients (NCT02565459) and liver transplant recipients (NCT02260375) using the same protocol design.

Thus, we propose to monitor the phenotype and function of immune cells in MSC-treated patients comprehensively and extensively in order to discover biomarkers of response to therapy and robust criteria for selecting responder patients amenable to immunosuppressive drug withdrawal at a given time after transplantation.

\section{Conclusions}

The available studies of MSC therapy in kidney disease and transplantation indicate the procedure is safe and feasible. To assess unwanted side effects, such as malignancies, MSC-treated patients should continue to be monitored long-term. Regarding efficacy, except promising results in kidney transplanta- 
tion and renovascular disease, the impression is that clinical study outcomes in AKI and CKD have fallen short of expectations raised by encouraging pre-clinical animal data.

There are several issues that need to be considered: i) MSC employed in clinical studies are very different regarding the procedure for ex vivo expansion, tissue of origin, source (autologous or allogeneic) and whether they come from academic or commercial cell factories, so it is difficult to interpret and compare the data from these studies; ii) even if an identical MSC preparation is used to treat several patients, the treatment outcome will be affected by variables such as disease stage and severity and concomitant immunosuppressive drugs; iii) we have only a vague idea of how MSC interact with the host's immune and nonimmune cells.

Therefore, future research on MSC therapy should focus on better understanding the MSC mechanism of action, whether they really need to reach the diseased organ to act beneficially, or whether they exert a systemic hit-and-run effect through the release of soluble mediators and microparticles or by undergoing apoptosis, ${ }^{88}$ eventually educating the host immune cells themselves to mitigate tissue damage and inflammation. A better understanding of how and where MSC have beneficial effects will allow development of effective MSC preparation, will inform the rational selection of patients who will benefit from MSC therapy, and will guide the rational design of the best clinical trial strategy to fully exploit MSC's potential. Questions regarding timing, whether to use multiple or single infusions, the minimum required dose, whether to use fresh or thawed MSC, autologous or allogeneic, and after minimal or extended in vitro expansion, are essential and need to be resolved definitively.

The field is still in its infancy and much work remains to be done. However, we believe that future research will move the clinical application of MSC-based therapy closer to being used for kidney diseases and transplantation.

\section{References}

1. Friedenstein AJ, Chailakhjan RK, Lalykina KS. The development of fibroblast colonies in monolayer cultures of guinea-pig bone marrow and spleen cells. Cell Tissue Kinet 1970;3:393-403.

2. Orbay H, Tobita M, Mizuno H. Mesenchymal stem cells isolated from adipose and other tissues: basic biological properties and clinical applications. Stem Cells Int 2012;2012:461718.

3. Arutyunyan I, Elchaninov A, Makarov A, Fatkhudinov T. Umbilical cord as prospective source for mesenchymal stem cell-based therapy. Stem Cells Int 2016;2016: 6901286 .
4. Flynn A, Barry F, O'Brien T. UC blood-derived mesenchymal stromal cells: an overview. Cytotherapy. 2007; 9:717-26.

5. Nicodemou A, Danisovic L. Mesenchymal stromal/stem cell separation methods: concise review. Cell Tissue Bank 2017;18:443-60.

6. Dominici M, Le Blanc K, Mueller I, et al. Minimal criteria for defining multipotent mesenchymal stromal cells. The International Society for Cellular Therapy position statement. Cytotherapy 2006;8:315-7.

7. Abbasalizadeh S, Pakzad M, Cabral JMS, Baharvand H. Allogeneic cell therapy manufacturing: process development technologies and facility design options. Exp Opin Biol Ther 2017;17:1201-19.

8. Dwarshuis NJ, Parratt K, Santiago-Miranda A, Roy K. Cells as advanced therapeutics: State-of-the-art, challenges, and opportunities in large scale biomanufacturing of high-quality cells for adoptive immunotherapies. Adv Drug Deliv Rev 2017;114:222-39.

9. Morigi M, Imberti B, Zoja C, et al. Mesenchymal stem cells are renotropic, helping to repair the kidney and improve function in acute renal failure. J Am Soc Nephrol 2004;15:1794-804.

10. Morigi M, Introna M, Imberti B, et al. Human bone marrow mesenchymal stem cells accelerate recovery of acute renal injury and prolong survival in mice. Stem Cells 2008;26:2075-82.

11. Morigi M, Rota C, Montemurro T, et al. Life-sparing effect of human cord blood-mesenchymal stem cells in experimental acute kidney injury. Stem Cells 2010;28:513-22.

12. Herrera MB, Bussolati B, Bruno S, et al. Exogenous mesenchymal stem cells localize to the kidney by means of CD44 following acute tubular injury. Kidney Int 2007;72:430-41.

13. Togel F, Hu Z, Weiss K, et al. Administered mesenchymal stem cells protect against ischemic acute renal failure through differentiation-independent mechanisms. Am J Physiol Renal Physiol 2005;289:F31-42.

14. Bruno S, Grange C, Deregibus MC, et al. Mesenchymal stem cell-derived microvesicles protect against acute tubular injury. J Am Soc Nephrol 2009;20:1053-67.

15. Perico L, Morigi M, Rota C, et al. Human mesenchymal stromal cells transplanted into mice stimulate renal tubular cells and enhance mitochondrial function. Nat Commun 2017;8:983.

16. Collino F, Bruno S, Incarnato D, et al. AKI recovery induced by mesenchymal stromal cell-derived extracellular vesicles carrying microRNAs. J Am Soc Nephrol 2015;26:2349-60.

17. Gatti S, Bruno S, Deregibus MC, et al. Microvesicles derived from human adult mesenchymal stem cells protect against ischaemia-reperfusion-induced acute and chronic kidney injury. Nephrol Dial Transplant 2011;26: 1474-83.

18. Lange $\mathrm{C}$, Togel F, Ittrich H, et al. Administered mesenchymal stem cells enhance recovery from ischemia/reperfusion-induced acute renal failure in rats. Kidney Int 2005;68:1613-7.

19. Eirin A, Zhu XY, Krier JD, et al. Adipose tissue-derived mesenchymal stem cells improve revascularization outcomes to restore renal function in swine atherosclerotic renal artery stenosis. Stem Cells 2012;30:1030-41.

20. Ebrahimi B, Eirin A, Li Z, et al. Mesenchymal stem cells 
improve medullary inflammation and fibrosis after revascularization of swine atherosclerotic renal artery stenosis. PLoS One 2013;8:e67474.

21. Zoja C, Garcia PB, Rota C, et al. Mesenchymal stem cell therapy promotes renal repair by limiting glomerular podocyte and progenitor cell dysfunction in adriamycininduced nephropathy. Am J Physiol Renal Physiol 2012; 303:F1370-81.

22. Guo J, Zou Y, Wu Z, et al. Protective effects of mesenchymal stromal cells on adriamycin-induced minimal change nephrotic syndrome in rats and possible mechanisms. Cytotherapy 2014;16:471-84.

23. Ezquer F, Ezquer M, Simon V, et al. Endovenous administration of bone-marrow-derived multipotent mesenchymal stromal cells prevents renal failure in diabetic mice. Biol Blood Marrow Transplant 2009;15:1354-65.

24. Wang S, Li Y, Zhao J, et al. Mesenchymal stem cells ameliorate podocyte injury and proteinuria in a type 1 diabetic nephropathy rat model. Biol Blood Marrow Transplant 2013;19:538-46.

25. Semedo P, Correa-Costa M, Antonio Cenedeze M, et al. Mesenchymal stem cells attenuate renal fibrosis through immune modulation and remodeling properties in a rat remnant kidney model. Stem Cells 2009;27:3063-73.

26. da Silva AF, Silva K, Reis LA, et al. Bone marrow-derived mesenchymal stem cells and their conditioned medium attenuate fibrosis in an irreversible model of unilateral ureteral obstruction. Cell Transplant 2015;24: 2657-66.

27. Matsui F, Babitz SA, Rhee A, et al. Mesenchymal stem cells protect against obstruction-induced renal fibrosis by decreasing STAT3 activation and STAT3-dependent MMP-9 production. Am J Physiol Renal Physiol 2017; 312:F25-32.

28. Gregorini M, Corradetti V, Pattonieri EF, et al. Perfusion of isolated rat kidney with mesenchymal stromal cells/extracellular vesicles prevents ischaemic injury. J Cell Mol Med 2017;21:3381-93.

29. Lv SS, Liu G, Wang JP, et al. Mesenchymal stem cells transplantation ameliorates glomerular injury in streptozotocin-induced diabetic nephropathy in rats via inhibiting macrophage infiltration. Int Immunopharmacol 2013;17:275-82

30. Fang Y, Tian X, Bai S, et al. Autologous transplantation of adipose-derived mesenchymal stem cells ameliorates streptozotocin-induced diabetic nephropathy in rats by inhibiting oxidative stress, pro-inflammatory cytokines and the p38 MAPK signaling pathway. Int J Mol Med 2012;30:85-92.

31. Nagaishi K, Mizue Y, Chikenji T, et al. Mesenchymal stem cell therapy ameliorates diabetic nephropathy via the paracrine effect of renal trophic factors including exosomes. Sci Rep 2016;6:34842.

32. Gregorini M, Corradetti V, Rocca C, et al. Mesenchymal stromal cells prevent renal fibrosis in a rat model of unilateral ureteral obstruction by suppressing the renin-angiotensin system via HuR. PLoS One 2016;11: e0148542.

33. Glennie S, Soeiro I, Dyson PJ, et al. Bone marrow mesenchymal stem cells induce division arrest anergy of activated T cells. Blood 2005;105:2821-7.

34. Krampera M, Glennie S, Dyson J, et al. Bone marrow mesenchymal stem cells inhibit the response of naive and memory antigen-specific $\mathrm{T}$ cells to their cognate peptide. Blood 2003;101:3722-9.

35. Meisel R, Zibert A, Laryea M, et al. Human bone marrow stromal cells inhibit allogeneic T-cell responses by indoleamine 2,3-dioxygenase-mediated tryptophan degradation. Blood 2004;103:4619-21.

36. Aggarwal S, Pittenger MF. Human mesenchymal stem cells modulate allogeneic immune cell responses. Blood 2005; 105:1815-22.

37. English K, Barry FP, Mahon BP. Murine mesenchymal stem cells suppress dendritic cell migration, maturation and antigen presentation. Immunol Lett 2008;115:50-8.

38. Chiesa S, Morbelli S, Morando S, et al. Mesenchymal stem cells impair in vivo T-cell priming by dendritic cells. Proc Natl Acad Sci U S A 2011;108:17384-9.

39. Wise AF, Williams TM, Kiewiet MB, et al. Human mesenchymal stem cells alter macrophage phenotype and promote regeneration via homing to the kidney following ischemia-reperfusion injury. Am J Physiol Renal Physiol 2014;306:F1222-35.

40. Asari S, Itakura S, Ferreri K, et al. Mesenchymal stem cells suppress B-cell terminal differentiation. Exp Hematol 2009;37:604-15.

41. Gu Z, Akiyama K, Ma X, et al. Transplantation of umbilical cord mesenchymal stem cells alleviates lupus nephritis in MRL/lpr mice. Lupus 2010;19:1502-14.

42. Chang JW, Hung SP, Wu HH, et al. Therapeutic effects of umbilical cord blood-derived mesenchymal stem cell transplantation in experimental lupus nephritis. Cell Transplant 2011;20:245-57.

43. Ma X, Che N, Gu Z, et al. Allogenic mesenchymal stem cell transplantation ameliorates nephritis in lupus mice via inhibition of B-cell activation. Cell Transplant 2013;22:2279-90.

44. Jang E, Jeong M, Kim S, et al. Infusion of human bone marrow-derived mesenchymal stem cells alleviates autoimmune nephritis in a lupus model by suppressing follicular helper T-cell development. Cell Transplant 2016;25:1-15.

45. English K, Ryan JM, Tobin L, et al. Cell contact, prostaglandin $\mathrm{E}(2)$ and transforming growth factor beta 1 play non-redundant roles in human mesenchymal stem cell induction of CD4+CD25(High) forkhead box P3+ regulatory T cells. Clin Exp Immunol 2009;156:149-60.

46. Selmani Z, Naji A, Zidi I, et al. Human leukocyte antigen-G5 secretion by human mesenchymal stem cells is required to suppress $\mathrm{T}$ lymphocyte and natural killer function and to induce CD4+CD25highFOXP3+ regulatory T cells. Stem Cells 2008;26:212-22.

47. Franquesa M, Mensah FK, Huizinga R, et al. Human adipose tissue-derived mesenchymal stem cells abrogate plasmablast formation and induce regulatory $\mathrm{B}$ cells independently of T helper cells. Stem Cells 2015; 33:880-91

48. Akiyama K, Chen C, Wang D, et al. Mesenchymalstem-cell-induced immunoregulation involves FAS-ligand-/FAS-mediated T cell apoptosis. Cell Stem Cell 2012;10:544-55

49. Casiraghi F, Azzollini N, Cassis P, et al. Pretransplant infusion of mesenchymal stem cells prolongs the survival of a semiallogeneic heart transplant through the generation of regulatory T cells. J Immunol 2008;181:3933-46.

50. Ge W, Jiang J, Arp J, et al. Regulatory T-cell generation 
and kidney allograft tolerance induced by mesenchymal stem cells associated with indoleamine 2,3-dioxygenase expression. Transplantation 2010;90:1312-20.

51. He Y, Zhou S, Liu H, et al. Indoleamine 2, 3-dioxgenase transfected mesenchymal stem cells induce kidney allograft tolerance by increasing the production and function of regulatory T cells. Transplantation 2015;99:1829-38.

52. Hobson CE, Yavas S, Segal MS, et al. Acute kidney injury is associated with increased long-term mortality after cardiothoracic surgery. Circulation 2009;119:2444-53.

53. Bihorac A, Yavas S, Subbiah S, et al. Long-term risk of mortality and acute kidney injury during hospitalization after major surgery. Ann Surg 2009;249:851-8.

54. Rewa O, Bagshaw SM. Acute kidney injury-epidemiology, outcomes and economics. Nat Rev Nephrol 2014;10:193-207.

55. Tonelli M, Manns B, Feller-Kopman D. Acute renal failure in the intensive care unit: a systematic review of the impact of dialytic modality on mortality and renal recovery. Am J Kidney Dis 2002;40:875-85.

56. Chertow GM, Burdick E, Honour M, et al. Acute kidney injury, mortality, length of stay, and costs in hospitalized patients. J Am Soc Nephrol 2005;16:3365-70.

57. Bagshaw SM. Short- and long-term survival after acute kidney injury. Nephrol Dial Transplant 2008;23:2126-8.

58. Gooch A, Doty J, Flores J, et al. Initial report on a phase i clinical trial: prevention and treatment of post-operative acute kidney injury with allogeneic mesenchymal stem cells in patients who require on-pump cardiac surgery. Cell Ther Transplant 2008;1:31-5.

59. Togel FE, Westenfelder C. Kidney protection and regeneration following acute injury: progress through stem cell therapy. Am J Kidney Dis 2012;60:1012-22.

60. Swaminathan M, Stafford-Smith M, Chertow GM, et al. Allogeneic mesenchymal stem cells for treatment of AKI after cardiac surgery. J Am Soc Nephrol 2018;29:260-7.

61. Gaspari F, Cravedi P, Mandala M, et al. Predicting cisplatin-induced acute kidney injury by urinary neutrophil gelatinase-associated lipocalin excretion: a pilot prospective case-control study. Nephron Clin Pract 2010; 115:c154-60.

62. Parikh CR, Thiessen-Philbrook H, Garg AX, et al. Performance of kidney injury molecule-1 and liver fatty acidbinding protein and combined biomarkers of AKI after cardiac surgery. Clin J Am Soc Nephrol. 2013;8:1079-88.

63. Yang X, Chen C, Teng S, et al. Urinary matrix metalloproteinase-7 predicts severe aki and poor outcomes after cardiac surgery. J Am Soc Nephrol 2017;28:3373-82.

64. Ruggenenti P, Cravedi P, Remuzzi G. Mechanisms and treatment of CKD. J Am Soc Nephrol 2012;23:1917-28.

65. Remuzzi G, Benigni A, Remuzzi A. Mechanisms of progression and regression of renal lesions of chronic nephropathies and diabetes. J Clin Invest 2006;116: 288-96.

66. Makhlough A, Shekarchian S, Moghadasali R, et al. Bone marrow-mesenchymal stromal cell infusion in patients with chronic kidney disease: a safety study with 18 months of follow-up. Cytotherapy 2018;20:660-9.

67. Nassar W, El-Ansary M, Sabry D, et al. Umbilical cord mesenchymal stem cells derived extracellular vesicles can safely ameliorate the progression of chronic kidney diseases. Biomater Res 2016;20:21.

68. Lotvall J, Hill AF, Hochberg F, et al. Minimal experi- mental requirements for definition of extracellular vesicles and their functions: a position statement from the International Society for Extracellular Vesicles. J Extracell Vesicles 2014;3:26913.

69. Saad A, Dietz AB, Herrmann SMS, et al. Autologous mesenchymal stem cells increase cortical perfusion in renovascular disease. J Am Soc Nephrol 2017;28: 2777-85.

70. Packham DK, Fraser IR, Kerr PG, Segal KR. Allogeneic Mesenchymal precursor cells (MPC) in diabetic nephropathy: a randomized, placebo-controlled, dose escalation study. EBioMed 2016;12:263-9.

71. Sun L, Akiyama K, Zhang H, et al. Mesenchymal stem cell transplantation reverses multiorgan dysfunction in systemic lupus erythematosus mice and humans. Stem Cells 2009;27:1421-32.

72. Gu F, Wang D, Zhang H, et al. Allogeneic mesenchymal stem cell transplantation for lupus nephritis patients refractory to conventional therapy. Clin Rheumatol 2014; 33:1611-9.

73. Wang D, Zhang H, Liang J, et al. A Long-term followup study of allogeneic mesenchymal stem/stromal cell transplantation in patients with drug-resistant systemic lupus erythematosus. Stem Cell Rep 2018;10:933-41.

74. Deng D, Zhang P, Guo Y, Lim TO. A randomised double-blind, placebo-controlled trial of allogeneic umbilical cord-derived mesenchymal stem cell for lupus nephritis. Ann Rheum Dis 2017;76:1436-9.

75. Chan TM, Tse KC, Tang CS, et al. Long-term study of mycophenolate mofetil as continuous induction and maintenance treatment for diffuse proliferative lupus nephritis. J Am Soc Nephrol 2005;16:1076-84.

76. Rovin BH, Parikh SV, Hebert LA, et al. Lupus nephritis: induction therapy in severe lupus nephritis-should MMF be considered the drug of choice? Clin J Am Soc Nephrol 2013;8:147-53.

77. Bartholomew A, Sturgeon C, Siatskas M, et al. Mesenchymal stem cells suppress lymphocyte proliferation in vitro and prolong skin graft survival in vivo. Exp Hematol 2002;30:42-8.

78. Ge W, Jiang J, Baroja ML, et al. Infusion of mesenchymal stem cells and rapamycin synergize to attenuate alloimmune responses and promote cardiac allograft tolerance. Am J Transplant 2009;9:1760-72.

79. Casiraghi F, Azzollini N, Todeschini M, et al. Localization of mesenchymal stromal cells dictates their immune or proinflammatory effects in kidney transplantation. Am J Transplant 2012;12:2373-83.

80. Casiraghi F, Perico N, Cortinovis M, Remuzzi G. Mesenchymal stromal cells in renal transplantation: opportunities and challenges. Nat Rev Nephrol 2016;12:241-53.

81. Reinders ME, de Fijter JW, Roelofs H, et al. Autologous bone marrow-derived mesenchymal stromal cells for the treatment of allograft rejection after renal transplantation: results of a phase I study. Stem Cells Transl Med 2013;2:107-11.

82. Pan GH, Chen Z, Xu L, et al. Low-dose tacrolimus combined with donor-derived mesenchymal stem cells after renal transplantation: a prospective, non-randomized study. Oncotarget 2016;7:12089-101.

83. Sun Q, Huang Z, Han F, et al. Allogeneic mesenchymal stem cells as induction therapy are safe and feasible in renal allografts: pilot results of a multicenter randomized controlled trial. J Transl Med 2018;16:52. 
84. Perico N, Casiraghi F, Introna M, et al. Autologous mesenchymal stromal cells and kidney transplantation: a pilot study of safety and clinical feasibility. Clin J Am Soc Nephrol 2011;6:412-22.

85. Perico N, Casiraghi F, Gotti E, et al. Mesenchymal stromal cells and kidney transplantation: pretransplant infusion protects from graft dysfunction while fostering immunoregulation. Transpl Int 2013;26:867-78.

86. Perico N, Casiraghi F, Todeschini M, et al. Long-term clinical and immunological profile of kidney transplant patients given mesenchymal stromal cell immunotherapy. Front Immunol 2018;9:1359.

87. Tan J, Wu W, Xu X, et al. Induction therapy with autologous mesenchymal stem cells in living-related kidney transplants: a randomized controlled trial. JAMA 2012;307:1169-77.

88. Galleu A, Riffo-Vasquez Y, Trento C, et al. Apoptosis in mesenchymal stromal cells induces in vivo recipient-mediated immunomodulation. Sci Transl Med 2017;9:416. 